\title{
РЕАЛИЗАЦИЯ НОРМ УГОЛОВНО-ИСПОЛНИТЕЛЬНОГО ПРАВА В ПРЕДУПРЕЖДЕНИИ ПРЕСТУПЛЕНИЙ
}

\author{
Гришко А.Я.
}

\begin{abstract}
Аннотация: Автором проанализирован механизм реализации норм уголовно-исполнительного права в предупреждении преступлений. Предметом изучения выступают нормы уголовно-испольнительного законодательства, имеющие ключевые значения в прочессе предупреждения преступлеий. В статье подчеркивается важность этапа подготовки осужденного к освобождению в деле постпенитенциарной адаптации, с одной стороны, в значительной степени декларативность соответствуюших норм уголовно-исполнительного права и отсутствия специализированной постпенитенциарной службы - с другой. Автором проведена подробная характеристика законодательного рассогласования и внесены предложения по его усовершенствованию. Методология исследования базируется на следуюших методах: сравнительный, системный, статистический анализ, метод причинноследственной связи, контент-анализ. В исследовании проблем предупреждении преступности, автором данной статьи были подробно проанализированы нормы уголовно-исполнительного права с точки зрения предупредительного воздействия. Выделены ключевые проблемные несоответствия в процессе реализации уголовно-исполнительного законодательства. Научная новизна статьи не только в том, что автор смог подойти к теме предупреждения преступлений с новой точки научного видения, но и внести ключевые предложения. В результате теоретических дискуссий, поиски практических путей совершенствования системы исполнения наказаний позволяет в значительной степени создать в России свою национальную структуру, опирающуюся при этом на прогрессивную систему исполнения наказания.
\end{abstract}

Ключевые слова: Нормы, уголовно-исполнительное право, осужденные, учет, состоят, постпенитенииарное предупреждение, проблема, режимы, условия, реализация.

Нет необходимости утверждать, что все нормы уголовно-исполнительного законодательства работают на предупреждение совершения новых преступлений как осужденными, так и иными лицами. В последнем случае выделяю, я прежде всего лица, не совершавших ранее преступления, и УИК РФ в отношении них играет обще нравственную роль, и лиц, освобожденных от дальнейшего отбывания наказания.

В данном случае интерес вызывает тема, почему те или иные нормы УИК РФ не работают в полной мере, пути и меры по их активизации.

Правильнее это сделать, оттолкнувшись от реальной криминологической ситуации, которая 
сегодня имеется в 6 местах лишения свободы. Именно последняя является наиболее значимой криминогенной, как с точки зрения предупреждения пенитенциарного, так и постпенитенциарного рецидива.

На 11 марта 2015 г. в исправительных колониях (722), колониях-поселениях (128), исправительных колониях для осужденных к пожизненному лишению свободы (6), в следственных изоляторах (219) и помещениях, функционирующих в режиме следственных изоляторов при колониях (108), в тюрьмах (8), в воспитательных колониях отбывало в среднем 553393 осужденных.

Что из себя представляют осужденные с точки зрения криминогенной опасности?

Из числа лишенных свободы 24707 (4,5 \%) являются злостными нарушителями установленного порядка отбывания наказания, 2168 из них содержатся в единых помещениях камерного типа; 22626 содержатся взапираемых помещениях для содержания осужденных в строгих условиях отбывания наказания, водворенных в штрафной изолятор, переведены в единые помещения камерного типа, одиночную камеру колонии строго режима.

Количество осужденных, состоящих на профилактическом учете, составляет 78424 человека, в том числе: склонных к побегу - 7372; лидеров и активных участников группировок отрицательной направленности, а также лиц, оказывающих негативное влияние на других осужденных - 1896; организующих и провоцирующих групповое противодействие требованиям администрации - 1271; склонные к употреблению и приобретению наркотических средств, психотропных веществ, сильнодействующих препаратов и алкогольных напитков - 11586.

По сравнению с 2013 в 2014 году произошло увеличение доли осужденных: склонных к суициду и членовредительству (на $30,1 \%$ ); организующих или активно участвующих в азартных играх с целью получения материальной или иной выгоды (на 10,11 \%); склонных к систематическому нарушению правил внутреннего распорядка (на 43,8 \%); изучающих, пропагандирующих, исповедующих либо распространяющих экстремистскую идеологию (на 43,1 \%); склонных к нападению на представителей администрации и иных сотрудников правоохранительных органов (на 31,0 \%); склонных к посягательству на половую свободу и половую неприкосновенность (на 5,6\%).

Обращает на себя внимание низкое качественное проведение профилактических мероприятий. Удельный вес осужденных, состоявших на профилактическом учете, совершавших преступления, увеличился на $20,0 \%$, в том числе побегов - на 50,0 \%.

При этом следует отметить остающийся на стабильно высоком уровне постпенитенциарной криминологический рецидив преступлений. В 2014 году лицами, ранее совершившими преступления, было совершено 632258 преступлений, прирост к 2013 году 3,0 \%[1].

Объяснить такую ситуацию в сфере борьбы с преступностью можно легко, апеллируя к сложной социально-экономической ситуации в стране. Но это будет очень легкое объяснение, которое можно подвести под любой социальный институт. Представляется необходимым в первую очередь разобраться с нормами действующего законодательства, насколько они синхронно работают, насколько обеспечены механизмом реализации.

Первое на что хотелось бы обратить внимание - на степень согласованности криминальных и социальных отраслей права в сфере предупреждения преступлений.

Одним из первых вопросов, который возникает в деле предупреждения преступлений лиц, освобожденных от дальнейшего отбывания наказания, кто этим должен заниматься. Исправительная колония после освобождения осужденного свои компетенции в отношении него теряет, органы полиции только фиксируют такое лицо путем постановки его на профилактический учет, а кто реально проводит с ним профилактическую работу, трудобытоустраивает, устраивает в социальные учреждения и др. 
Представители уголовно-исполнительного права (В.А. Уткин, В.Е. Южанин) говорят, что этим должны заниматься социальные службы[2]. В идеале, наверное, так и должно быть.

Практически получается, что постпенитенциарное предупреждение преступлений не является предметом какой-либо конкретной одной отрасли права. Хотя из содержания Концепции развития уголовно-исполнительной системы Российской Федерации до 2020 года следует, что этот период в жизни бывшего осужденного является предметом уголовноисполнительной политики. Но эта политика не получает своего материального воплощения, позиции ее в значительной степени остаются декларативными.

На мой взгляд, законодательная регламентация вопросов постпенитенциарной адаптации включает в себя и период подготовки осужденного к освобождению, что является однозначно предметом уголовно-исполнительного права. Здесь следует заметить, что уголовно-исполнительное законодательство содержит и нормы, которые определяют вопросы данной адаптации и после освобождения от дальнейшего отбывания наказания. Речь идет о ч. 3 ст. 180 УИК РФ и ст. 173.1 - «Установление административного надзора в отношении лица, освобожденного из мест лишения свободы».

Данные нормы противоречат устоявшейся в теории уголовного-исполнительного права точки зрения относительно прекращения уголовно-исполнительных правоотношений после освобождения осужденного от дальнейшего отбывания наказания.

Важность этапа подготовки осужденного к освобождению в деле постпенитенциарной адаптации, с одной стороны, в значительной степени декларативность соответствующих норм уголовно-исполнительного права и отсутствия специализированной постпенитенциарной службы (службы пробации), с другой, обуславливает повышенное внимание к данному вопросу в рамках, если не уголовно-исполнительного права, то уголовно-исполнительной политики.
Это вытекает и из документов, определяющих основные направления уголовно-исполнительной политики в ближайшие годы и на перспективу. Речь идет о Концепции развития уголовно-исполнительной системы Российской Федерации до 2020 года и решении оперативного совещания Совета Безопасности Российской Федерации «О мерах по предупреждению рецидивной преступности в Российской Федерации от 07.02.2011 г. № ПР-301.

Какие выходы видятся здесь. Автор видит их три: 1) систематизация соответствующих норм в одной отрасли права (постпенитенциарное право); 2) создание службы пробации[3]; 3) превентивное заключение (по примеру Германии).

Однако, в силу материальных, инертных и других аспектов все они не могут быть осуществлены одномоментно.

Здесь следует заметить, что в результате теоретических дискуссий, поиски практических путей совершенствования системы исполнения наказаний позволяет в значительной степени создать в России свою национальную структуру, опирающуюся при этом на прогрессивную систему исполнения наказания. Говоря словами А.C. Макаренко речь идет о перспективных направлениях осужденных (помещение осужденных в обычные, облегченные, строгие условия отбывания наказания).

«Но как сохранить объективность при оценке родного, отечественного уголовного закона, уголовно-правовых идей, уголовно-правовой науки? Способ единственный - сопоставление, например, отечественного уголовно-правового закона с западным»[4], - пишет А.В. Наумов.

На сей счет, как раз, уместно привести Резолюцию Европейской конференции директоров тюремных ведомств (Эдинбурге, Шотландия, 2009 г.), содержащую следующий пункт: «Следует пересмотреть концепцию современной тюрьмы. Сложилось представление о тюрьме, как о сооружении, окруженном высокими стенами, с запорами и засовами, где заключенные находятся под постоянным надзором и контролем. Россия подает другой пример организации лишения 
свободы: основной вид учреждения - исправительная колония, в которой осужденные имеют относительную свободу передвижения в рамках контролируемой и охраняемой территории. Одновременно во многих европейских государствах наметилась опасная тенденция строительства особо охраняемых тюрем с жестким режимом содержания. Совету Европы следует обсудить этот вопрос» [5].

Следующую группу проблем можно обозначить как отсутствие внутреннего единства уголовного и уголовно-исполнительного законодательства, и рассогласование с конституционными нормами, декларативность норм уголовно-исполнительного права.

В нынешнем законодательстве примеров рассогласования, декларативности множество. В их числе:

1) внутреннее рассогласование норм УИК РФ:

- определение целей и задач уголовно-исполнительного законодательства (ст. 1 УИК РФ) и их отсутствие относительно исполнения наказания;

- определение случаев учета личности осужденного наряду с другими показателями, которые по своей сути характеризуют ее (ч. 3 ст. 9, ч. 1 ст. 117 УИК РФ);

2) внешнее рассогласование норм УИК РФ и УК РФ:

- наличие принципов вины и справедливости в УК РФ и их отсутствие в УИК РФ; раскрытие содержания принципов уголовной ответственности в УК РФ и его отсутствие относительно принципов исполнения наказаний в УИК РФ (действующий УИК РФ устанавливает принципы уголовноисполнительного законодательства).

Действующее уголовно-исполнительное законодательство содержит немало норм, направленных непосредственно на профилактику преступлений, как во время отбывания наказания, так и после освобождения от его дальнейшего отбывания. Однако, в значительной части они не «работают». Приведу следующий пример: согласно ч. 3 ст. 120 УИК РФ осужденные, отбывающие наказание в облегченных условиях, в целях успешной социальной адаптации, могут быть по постановлению начальника исправительной колонии за шесть месяцев до окончания срока наказания освобождены из-под стражи.

В этом случае им разрешается проживать и работать под надзором администрации исправительного учреждения за пределами исправительной колонии. Осужденным женщинам может быть разрешено проживание за пределами исправительной колонии совместно с семьей или детьми на арендованной или собственной жилой площади. Однако в 2014 году такое разрешение было получено всего 24 осужденными.

Здесь возникает и другой вопрос: Соответствия данной норме Конституции Российской Федерации: «Мужчина и женщина имеют равные права и свободы и равные возможности для их реализации» (ч.3 ст. 19).

Непонятно по каким причинам законодатель норму относительно разрешения осужденным женщинам проживать за пределами исправительной колонии совместно с семьей или детьми на арендованной или собственной жилой площади, выделил в качестве особенной по отношению к осужденным мужчинам.

Осужденные мужчины тоже имеют возможность арендовать или иметь собственное жилье. При этом они положительно характеризуются (не имеют взысканий за нарушения установленного порядка отбывания наказания, добросовестно относятся к труду) - ч. 2 ст. 120 УИК РФ.

Приведенные и другие частные примеры наличия норм в УИК РФ, регламентирующие права и законные интересы осужденных в определенной степени в декларативной форме, конкретные предложения по совершенствованию тех или иных его норм приводят к выводу, что требуется не его «латание», а создание совершенно нового кодекса. Нормы такого кодекса должны быть согласованными внутри и на межотраслевом уровне. В последнем случае речь идет прежде всего о их согласованности с нормами уголовного и уголовно-процессуального законодательства. Внимание в указанном плане должны получить соответствующие установления административного и публичного права. 
По мнению автора, основными идеями, которые должны воплотиться в новый уголовноисполнительный кодекс, должны быть:

1. Наказания в виде лишения свободы должны заключаться в самом факте изоляции от общества. Во всем остальном правовое положение осужденного не должно отличаться от правового положения других граждан за определенными исключениями, обусловленными фактом изоляции. На законодательном уровне должен быть определен исчерпывающий перечень запретов и ограничений для осужденных. Возможности администрации исправительного учреждения по ухудшению правового положения осужденного должны быть исключены.
Административное усмотрение может допускаться в целях его улучшения.

2. В основе определения режимов и условий отбывания лишения свободы должны быть положены личностные особенности осужденного, а не наоборот - «подгонка» личности осужденного под них. В этих целях требуется законодательная классификация осужденных. В качестве ее варианта могут быть следующие распределения осужденных: неопределенные (недостаточно изученные), нейтральные; вставшие на путь исправления; твердо вставшие на путь исправления; доказавшие свое исправление; нарушители условий и порядка отбывания наказания; злостные нарушители условий и порядка отбывания наказания.

\section{Библиография:}

1. Состояние преступности в России за январь - декабрь 2014 года. М., 2015. С. 44.

2. Уткин В.А. Правовые основы ресоциализации освобожденных из мест лишения свободы // Актуальные проблемы исполнения уголовных наказаний. Рязань. 2005. С. 46-47.

3. Южанин В.Е. Проблемы правового регулирования преемственности работы по подготовке осужденных к освобождению и управлению их социальной адаптацией к условиям свободы // Международный непитенциарный форум «Преступление, наказание и исправление (к 20-летию принятия Конституции Российской Федерации): сб. тез. выступлений участников (Рязань, 5-6 декабря 2013 г.). Рязань. 2013. С. 180.

4. Клинов С.А. Контроль за лицами, освобожденными из исправительных учреждений. Дис. канд. юрид. наук. Рязань. 2012.

5. Наумов А.В. Контроль и надзор в системе предупреждения рецидива преступлений. Дис. канд. юрид. наук. Рязань. 2014. С. 120-127.

6. Наумов А.В. Преступление и наказание в истории России. В 2 ч. Ч. 1. М. 2014. С. 8.

7. Overcrowded Prisons: Looking for Solutions: Conclusion by the General Rapporteur of the $15^{\text {th }}$ Conference of Directors of Prison Administration (Edinburg. 9-11 Sept. 2009). P. 5.

\section{References (transliterated):}

1. Sostoyanie prestupnosti v Rossii za yanvar' - dekabr' 2014 goda. M., 2015. S. 44.

2. Utkin V.A. Pravovye osnovy resotsializatsii osvobozhdennykh iz mest lisheniya svobody // Aktual'nye problemy ispolneniya ugolovnykh nakazanii. Ryazan'. 2005. S. 46-47.

3. Yuzhanin V.E. Problemy pravovogo regulirovaniya preemstvennosti raboty po podgotovke osuzhdennykh k osvobozhdeniyu i upravleniyu ikh sotsial'noi adaptatsiei k usloviyam svobody // Mezhdunarodnyi nepitentsiarnyi forum «Prestuplenie, nakazanie i ispravlenie (k 20-letiyu prinyatiya 
Konstitutsii Rossiiskoi Federatsii): sb. tez. vystuplenii uchastnikov (Ryazan', 5-6 dekabrya 2013 g.). Ryazan'. 2013. S. 180.

4. Klinov S.A. Kontrol' za litsami, osvobozhdennymi iz ispravitel'nykh uchrezhdenii. Dis. kand. yurid. nauk. Ryazan'. 2012.

5. Naumov A.V. Kontrol' i nadzor v sisteme preduprezhdeniya retsidiva prestuplenii. Dis. kand. yurid. nauk. Ryazan'. 2014. S. 120-127.

6. Naumov A.V. Prestuplenie i nakazanie v istorii Rossii. V 2 ch. Ch. 1. M. 2014. S. 8.

7. Overcrowded Prisons: Looking for Solutions: Conclusion by the General Rapporteur of the $15^{\text {th }}$ Conference of Directors of Prison Administration (Edinburg. 9-11 Sept. 2009). P. 5. 